Jurnal Civic Education, Vol. 1 No. 1 Juni 2017

\title{
UPAYA MENINGKATKAN KEMAMPUAN BELAJAR BIDANG STUDI PPKn MELALUI PENERAPAN METODE DIALOG PADA SISWA DI SMK WONOKROMO SURABAYA
}

\author{
Drs. Lukman Hakim. S.Pd.SH.SE.MM.M.Si \\ Dosen UNITAS/STKIP Tribhuana Surabaya
}

\begin{abstract}
Abstrak
Masalah pokok penelitian ini adalah untuk mengetahui seberapa jauh kemampuan siswa belajar PKn dan upaya-upaya apa saja yang dapat meningkatkan kemampuan siswa dalam belajar PKn. Tujuan penelitian yang hendak dicapai adalah sebagai berikut: 1. Mengetahui ada tidaknya perbedaan yang signifikan sebelum dan sesudah penerapan metode dialog pada mata pelajaran PKn. 2. Meningkatkan kemampuan belajar bidang studi PKn dengan menerapkan metode dialog. 3. Mengetahui kendala-kendala yang dihadapi guru dalam menerapkan metode dialog pada mata pelajaran PKn. kesimpulan sebagai berikut: 1. Ada perbedaan nilai PKn sebelum dan setelah penerapan metode dialog pada mata pelajaran PKn signifikan. 2 . Penerapan metode dialog dalam pembelajaran PKn berhasil meningkatkan kemampuan belajar PKn siswa kelas XI di SMK Wonokromo Surabaya. Hal ini terbukti dari hasil penelitian yang dilakukan, antara lain: Dengan metode, Pembelajaran ini lebih efisien dan etektif jika diterapkan dengan baik, terutama pada mata pelajaran PKn yang ruang lingkup pengajarannya mempunyai tujuan agar siswa terampil dalam hal menyimak, berbicara, membaca, memahami dan mengerjakan soal. 3. Kendala-kendala yang dihadapi guru dalam menerapkan prinsip pembelajaran integratif pada siswa kelas XI di SMK Wonokromo Surabaya adalah: a. Siswa kurang percaya diri dalam menyelesaikan setiap kegiatan yang dibebankan. b. Hasil observasi peneliti di kelas memperlihatkan adanya beberapa ciri siswa yang memiliki cara berpikir yang berbeda-beda yaitu ada yang mampu menyesuaikan diri, menyukai tantangan, bertanggungjawab, mandiri, dan ada pula yang cenderung kurang aktif. Kondisi ini membutuhkan keaktifan guru dalam mengajar, sehingga kegiatan belajar mengajar tetap dapat berjalan dengan baik.

Penelitian ini menyarankan: 1 . adanya penerapan metode dialog dapat mempengaruhi tingkat prestasi siswa dalam belajar. 2. direkomendasikan kepada berbagai pihak untuk meningkatkan pengelolaan fasilitas sekolah agar layanan pembelajaran lebih bermutu yang pada akhirnya akan meningkatkan kualitas mutu siswa-siswinya dan juga para pengajar atau guru. 3. Pembelajaran lebih diarahkan pada cara membaca, memahami dan berdiskusi, menggunakan komunikasi lisan dan tata bahasa dengan baik. Keberhasilan penerapan pembelajaran dengan metode dialog perlu melibatkan berbagai pihak.
\end{abstract}

Kata Kunci: Kemampuan Belajar, PPKn, Metode Dialog 


\section{Pendahuluan}

Pendidikan adalah usaha sadar untuk menumbuhkan kembangkan potensi sumber daya manusia melalui kegiatan pengajaran. UU Sistem Pendidikan Nasional No. 20 tahun 2003, menyatakan, bahwa tujuan pendidikan nasional adalah mencerdaskan kehidupan bangsa dan mengembangkan manusia Indonesia seutuhnya yaitu manusia yang bertakwa terhadap Tuhan Yang Maha Esa dan berbudi pekerti luhur, memiliki pengetahuan dan keterampilan, kesehatan jasmani dan rohani, kepribadian yang mantap dan mandiri serta tanggung jawab kemasyarakatan dan kebangsaan.

Komitmen yang kuat dan konsisten terhadap prinsip dan semangat kebangsaan dalam kehidupan bermasyarakat, berbangsa dan bernegara yang berdasarkan Pancasila dan UUD 1945, perlu ditingkatkan terus menerus untuk memberikan pemahaman yang mendalam tentang Negara Kesatuan Republik Indonesia. Konstitusi Negara Republik Indonesia perlu ditanamkan kepada seluruh komponen bangsa Indonesia, khususnya generasi muda sebagai generasi penerus.

Indonesia harus menghindari sistem pemerintahan yang memasung hak-hak asasi manusia, hak-hak warganegara untuk dapat menjalankan prinsip-prinsip demokrasi. Kehidupan yang demokratis didalam kehidupan sehari-hari di lingkungan keluarga, sekolah, masyarakat, pemerintahan, dan organisasiorganisasi non pemeritahan perlu dikenal, dipahami, diinternalisasi, dan diterapkan demi terwujudnya pelaksanaan prinsip-prinsip demokrasi serta demi peningkatan martabat kemanusian, kesejahteraan, kebahagiaan, kecerdasan dan keadilan.

$$
\text { Mata Pelajaran Pendidikan }
$$

Kewarganegaraan merupakan mata pelajaran yang memfokuskan pada pembentukan warganegara yang memahami dan mampu melaksanakan hak-hak dan kewajibannya untuk menjadi warga Negara yang baik, yang cerdas, terampil, dan berkarakter yang diamanatkan oleh Pancasila dan UUD 1945. Pendidikan Kewarganegaraan (Citizenship Education) merupakan mata pelajaran yang memfokuskan pada pembentukan diri yang beragam dari segi agama, sosio-kultural, bahasa, usia, dan suku bangsa.

Dalam Kurikulum Tingkat Satuan Pendidikan Sekolah Dasar, ditegaskan bahwa: Tujuan Pendidikan Dasar adalah meletakkan dasar kecerdasan, pengetahuan, kepribadian, akhlak mulia, serta keterampilan untuk hidup mandiri dan mengikuti pendidikan lebih lanjut. Standar isi Pendidikan Kewarganegaraan adalah sebagai berikut:

1. Menguasai materi keilmuan yang meliputi dimensi pengetahuan, sikap, nilai, dan perilaku yang mendukung kegiatan pembelajaran PKn.

2. Menguasai konsep dan prinsip kepribadian nasional dan demokrasi konstitusional Indonesia, semangat kebangsaan dan cinta tanah air serta bela Negara.

3. Menguasai konsep dan prinsip perlindungan, kemajuan HAM, serta penegakan hukum secara adil dan benar.

Dari Standar Isi dan Standar Kompetensi tersebut diatas, penulis memilih butir ketiga yaitu tentang Hak Asasi Manusia, serta penegakan hukum secara adil dan benar, sebagai landasan judul penelitian ini.

Pengajaran PKn untuk siswa Sekolah Menengah Pertama perlu mendapat perhatian, hal ini dikarenakan dengan pembelajaran atau pemberian bekal ilmu mengenai PKn akan dapat mempermudah bagi siswa untuk mengadaptasikan atau mengkomunikasikan bahasa yang akan mereka ungkapkan dengan benar, jelas, dan baik. Melalui pengajaran PKn, anak-anak berlatih membaca, menulis, berbicara, dan mendengarkan dalam PPKn. PPKn diajarkan sejak Sekolah Dasar hingga perguruan tinggi.

Berdasarkan hasil pengamatan dan pengalaman selama ini, siswa kurang aktif dalam kegiatan belajar-mengajar. Anak cenderung tidak begitu tertarik dengan pelajaran PKn karena selama ini pelajaran PKn dianggap sebagai pelajaran yang hanya mementingkan hafalan semata, kurang menekankan aspek penalaran sehingga menyebabkan rendahnya minat belajar PKn siswa di sekolah.

Banyak faktor yang menyebabkan hasil belajar PKn siswa rendah yaitu faktor internal dan eksternal dari siswa. Faktor internal antara 
lain: motivasi belajar, intelegensi, kebiasan dan rasa percaya diri. Sedangkan faktor eksternal adalah faktor yang terdapat di luar siswa, seperti; guru sebagai Pembina kegiatan belajar, startegi pembelajaran, sarana dan prasarana, kurikulum dan lingkungan.

Dari masalah-masalah yang dikemukakan diatas, perlu dicari strategi baru dalam pembelajaran yang melibatkan siswa secara aktif. Pembelajaran yang mengutamakan penguasaan kompetensi harus berpusat pada siswa (Focus on Learners), memberikan pembelajaran dan pengalaman belajar yang relevan dan kontekstual dalam kehidupan nyata (provide relevant and contextualized subject matter) dan mengembangkan mental yang kaya dan kuat pada siswa.

Disinilah guru dituntut untuk merancang kegiatan pembelajaran yang mampu mengembangkan kompetensi, baik dalam ranah kognitif, ranah afektif maupun psikomotorik siswa. Strategi pembelajaran yang berpusat pada siswa dan peciptaan suasana yang menyenangkan sangat diperlukan untuk meningkatkan hasil belajar siswa dalam mata pelajaran PKn. Dalam hal ini penulis memilih model "pembelajaran berbasis masalah (Problem Based Learning) dalam meningkatkan kemampuan memecahkan masalah HAM dalam mata pelajaran PKn".

Pembelajaran berbasis masalah adalah suatu proses belajar mengajar didalam kelas dimana siswa terlebih dahulu diminta mengobservasi suatu fenomena. Kemudian siswa diminta untuk mencatat permasalahanpermasalahan yang muncul, setelah itu tugas guru adalah merangsang untuk berfikir kritis dalam memecahkan masalah yang ada. Tugas guru mengarahkan siswa untuk bertanya, membuktikan asumsi, dan mendengarkan persfektif yang berbeda diantara mereka.

Pembelajaran PPKn harus bersifat aktual, fleksibel, dinamis, kontekstual, dan lebih mengutamakan metode dialog dan diskusi daripada ceramah. Aktual berarti nyata dan masih hangat dalam kehidupan sehari-hari, bukan suatu pengandaian. Bersifat fleksibel, maksudnya tidak terlalu tegang, terpancang pada satu metode dan satu sumber buku. Dinamis, artinya sesuai dengan perkembangan jaman. Bersifat kontekstual, berarti sesesuai dengan konteks lingkungan dan sistem sosial yang berlaku.

Dari gambaran kondisi di atas, sebagai guru PKn harus mengupayakan peningkatan kemampuan belajar siswa terhadap pelajaran PKn dengan menerapkan metode dialog daripada ceramah. Oleh karena itu, hal yang perlu diperhatikan dalam hal ini adalah melatih siswa membaca, mendengarkan, dan berdiskusi sebanyak-banyaknya. Dengan pelaksanaan pembelajaran yang tepat ini akan meningkatkan kompetensi siswa.

Penelitian ini diharapkan dapat mengetahui seberapa jauh kemampuan siswa belajar PKn dan upaya-upaya apa saja yang dapat meningkatkan kemampuan siswa dalam belajar PKn.

Berdasarkan latar belakang di atas maka dapat dirumuskan secara umum dalam suatu penelitian di dalam kelas tersebut adalah sebagai berikut:

1. Apakah ada perbedaan yang signifikan sebelum dan sesudah penerapan metode dialog pada mata pelajaran PKn?

2. Apakah dengan penerapan metode dialog, kemampuan belajar PKn dapat ditingkatkan?

3. Kendala-kendala apa sajakah yang dihadapi guru dalam menerapkan metode dialog pada mata pelajaran $\mathrm{PKn}$ ?

\section{Landasan Teori \\ Pengertian Belajar}

Belajar adalah merupakan suatu aktifitas yang dilakukan oleh murid / manusia dengan tujuan untuk dapat melaksanakan atau melakukan sesuatu yang baru. Manusia atau individu telah melakukan perbuatan belajar di dalam dirinya berarti pula bahwa telah terjadi perubahan, baik berupa pengetahuan, sikap, ketrampilan yang sebelumnya belum pernah dimiliki. Sedangkan menurut Winarno Surachmad dikatakan bahwa belajar: Proses perubahan yang terjadi pada/dalam diri manusia yaitu tidak tahu kearah mengetahui dan berlangsung secara berencana dan bertujuan.

Dengan begitu belajar adalah suatu aktifitas yang dilakukan seseorang sehingga terjadi perubahan pada dirinya baik dalam bentuk ketrampilan, sikap, pengetahuan, 
kebiasaan dan lain-lain yang berlangsung secara berencana dan tujuan. Prestasi belajar merupakan bukti utama dari suatu keberhasilan dari seseorang siswa di dalam menuntut ilmu baik dengan jalan melalui pendidikan formal maupun informal. Di dalam pendidikan formal dituntut suatu peraturan atau kedisiplinan yang ketat dan umumnya keberhasilan seseorang siswa dinyatakan dalam prestasi tersebut, diukur dengan menggunakan lambang nilai suatu misal ada yang menggunakan angka-angka 1-10 atau angka puluhan 10-100 adapun yang menggunakan abjad A,B,C dan D atau angkaangka kurang, cukup, memuaskan dan sangat memuaskan. Menurut W.J.S. Poerwodarminta (th 1977, hal.768) yang dimaksud dengan prestasi adalah hasil yang telah dicapai atau dilaksanakan atau dikerjakan.

\section{Macam-macam Teori Belajar}

Teori belajar yang oleh para ahli menurut Singgih D. Gunarso (th. 1973, hal. 25) antara lain sebagai berikut:

a. Belajar Secara Assosiatif.

Cara belajar menurut teori ini adalah merupakan proses belajar yang sederhana, karena hanya menyangkut soal assosiatif antara suatu rangsang dengan respon atau suatu cara adanya rangsang yang menyebabkan timbulnya assosiatif dengan respon.

b. Belajar menurut Hukum Pertautan (teori Consotions)

Hukum ini berlandaskan suatu pendapat bahwa hal belajar sebenarnya merupakan suatu rangkaian hubungan antara rangsangan dan liku-liku (perbuatan-perbuatan) yang diperhatikan hokum ini dikemukakan oleh Thorndiks.

\section{Faktor-faktor yang mempengaruhi Proses Belajar}

Faktor-faktor yang mempengaruhi proses belajar itu sebanyak ragam diantaranya:

1. Kondisi belajar Untuk dapat belajar dengan efektif dan efisien tergantung pada kondisi fisik orang yang belajar.

2. Situasi Belajar
Maksudnya kondisi yang baik belajar akan besar sekali pengaruhnya terhadap proses belajar misalnya kesehatan badan, keadaan. Keadaan fisik yang baik motif yang murni dalam bentuk tujuan yang benar-benar di idam-idamkan pelajar belajar akan efektif apabila keadaan jiwa anak tidak mengalami gangguan-gangguan, misalnya adanya gangguan oleh suatu hal atau pemusatan minat terhadap yang lain.

\section{Pendidikan Pancasila dan Kewarganegaraan \\ Pendidikan Pancasila dan}

Kewaarganegaraan sudah sejak tahun 1976 dan mulai diajarkan mulai TK sampai perguruan tinggi. Disamping itu dengan adanya bidang studi Pendidikan Pancasila dan Kewarganegaraan dan Ilmu Pengetahuan Sosial, kedua bidang ini obyeknya sama yaitu masyarakat, warga Negara yang baik, tetapi perbedaannya terletak dalam penelitian dan sasarannya saja. Pendidikan Pancasila dan Kewarganegaraan penekanannya pada pembinaan sikap warga Negara yang sesuai dengan Pancasila sebagai filsafat bangsa. Sedangkan Ilmu Pengetahuan Sosial menekankan ketrampilan warga Negara dalam menghadapi dan memecahkan masalah sosial masyarakat. Sedangkan S. Brojonegoro merumuskan pengertian pendidikan adalah sebagai berikut:

“ Pendidikan merupakan tuntutan kepada manusia yang belum dewasa untuk menyiapkan agar dapat memenuhi sendiri tugas hidupnya atau secara singkat pendidikan adalah tuntunan kepada perkembangan manusia mulai lahir sampai tercapainya kedewasaan dalam arti jasmani dan rokhaniah"

Dalam artian khusus untuk Indonesia, sesuai dengan ketetapan MPR No. I/MPR/1973 pengertian pendidikan dirumuskan sebagai berikut:

"Pendidikan pada hakekatnya adalha usaha sadar untuk mengembangkan kepribadian dan kemampuan di dalam dan di luar sekolah dan berlangsung seumur hidup" 


\section{Pengajaran Pendidikan Kewarganegaraan (PKn)}

Pendidikan kewarganegaraan adalah sebagai wahana untuk mengembangkan kemampuan, watak dan karakter warganegara yang demokratis dan bertanggung jawab.

Ada beberapa hal yang perlu diperhatikan dalam pelajaran PKn dalam rangka "nation and character building", yaitu:

1. PKn merupakan bidang kajian kewarganegaraan yang ditopang berbagai disiplin ilmu yang releven, yaitu: ilmu politik, hukum, sosiologi, antropologi, psokoliogi dan disiplin ilmu lainnya yang digunakan sebagai landasan untuk melakukan kajian-kajian terhadap proses pengembangan konsep, nilai dan perilaku demokrasi warganegara.

2. PKn mengembangkan daya nalar (state of mind) bagi para peserta didik. Pengembangan karakter bangsa merupakan proses pengembangan warganegara yang cerdas dan berdaya nalar tinggi. PKn memusatkan perhatiannya pada pengembangan kecerdasan warga negara (civic intelegence) sebagai landasan pengembangan nilai dan perilaku demokrasi.

3. PKn sebagai suatu proses pencerdasan, maka pendekatan pembelajaran yang digunakan adalah yang lebih inspiratif dan partisipatif dengan menekankan pelatihan penggunaan logika dan pealaran. Untuk menfasilitasi pembelajaran PKn yang efektif dikembangkan bahan pembelajaran yang interaktif yang dikemas dalam berbagai paket seperti bahan belajar tercetak, terekam, tersiar, elektronik, dan bahan belajar yang digali dari ligkungan masyarakat sebagai pengalaman langsung (hand of experience).

4. Kelas PKn sebagai laboratorium demokrasi. Melalui PKn, pemahaman sikap dan perilaku demokratis dikembangkan bukan semata-mata melalui "mengajar demokrasi" (teaching democracy), tetapi melalui model pembelajaran yang secara langsung menerapkan cara hidup secara demokrasi (doing democracy). Penilaian bukan sematamata dimaksudkan sebagai alat kedali mutu tetapi juga sebagai alat untuk memberikan bantuan belajar bagi siswa sehingga lebih dapat berhasil dimasa depan.

PKn sebagai salah satu bidang studi yang memiliki tujuan "How to Develop Better Civics Behaviours" membekali siswa untuk mengembangkan penalarannya disamping aspek nilai dan moral, banyak memuat materi sosial. PKn merupakan salah satu dari lima tradisi pendidikan IPS yakni citizenship transmission, saat ini sudah berkembang menjadi tiga aspek PKn (Citizenship Education), yakni aspek akademis, aspek kurikuler dan aspek sosial budaya.

Secara akademis PKn dapat didefinisikan sebagai suatu bidang kajian yang memusatkan telaahannya pada seluruh dimensi psikologi dan sosial budaya kewarganegaraan individu dengan menggunakan ilmu politik dan pendidikan sebagai landasan kajiannya.

Implementasiya sangat dibutuhkan guru yang profesional, guru yang profesional dituntut menguasai sejumlah kemampuan dan keterampilan, antara lain :

1. Kemampuan menguasai bahan ajar

2. Kemampuan dalam mengelola kelas

3. Kemampuan dalam menggunakan metode, media dan sumber belajar

4. Kemampuan untuk melakukan penilaian baik proses maupun hasil

Dalam melaksanakan kegiatan pembelajaran ada beberapa prinsip yang perlu diperhatikan, yaitu (1) berpusat pada peserta didik, (2) mengembangkan peserta didik, (3) meciptakan kondisi menyenangkan dan menantang., (4) mengembangkan beragam kemampuan yang bermuatan nilai, (5) menyediakan pengalaman belajar yang beragam,, dan (6) belajar melalui berbuat. (http://krisnaster.blogspot.com).

Yang perlu dibenahi adalah metode penyampaian pelajaran PKn . Pembelajaran PKn harus bersifat aktual, fleksibel, dinamis, kontekstual, dan lebih mengutamakan metode dialog dan diskusi daripada ceramah. Aktual berarti nyata dan masih hangat dalam kehidupan sehari-hari, bukan suatu pengandaian. Bersifat fleksibel, maksudnya tidak terlalu tegang, terpancang pada satu metode dan satu sumber buku. Dinamis, artinya sesuai dengan perkembangan jaman. Bersifat kontekstual, 
berarti sesesuai dengan konteks lingkungan dan sistem sosial yang berlaku. (http://krisnaster.blogspot.com)

Mata pelajaran PKn tidak boleh hanya pada hafalan semata. Jika hanya hafalan, artinya pelajaran PKn selama ini masih dangkal dan belum menyentuh dua fungsi utama di atas. Pelajaran PKn harus mencapai dasar-dasar yang bersifat reflektif. Sekaligus dalam kerangka kurikulum berbasis kompetensi, siswa juga perlu diberdayakan. Jangan sampai model ceramah yang membosankan mendominasi metode pembelajaran PKn . Baiknya, model yang digunakan adalah model yang membuat siswa aktif. Siswa harus mencari dan menemukan sendiri nilai-nilai demokrasi Indonesia dan hakekat Pancasila. Metode yang dipakai bisa dalam bentuk presentasi kelompok, diskusi atau dengan metode yang lebih menarik seperti metode debat. Sumber yang digunakan juga jangan berkutat pada sumber buku paket dari pemerintah. Itu akan menyebabkan kebosanan. Akan lebih baik jika digunakan sumber-sumber lain selain buku paket yang aktual dan menarik. (http://krisnaster.blogspot.com)

Dari pihak siswa juga diharapkan ada respon positif akan metode baru yang ditawarkan. Sikap negative thinking terhadap PKn harus dihindari. Sebaliknya, harus disadari peran penting PKn dalam kehidupan berbangsa dan bernegara. (http://krisnaster.blogspot.com)

\section{Metode Penelitian}

\section{Deskripsi Populasi dan Penentuan Sampel}

Subyek dalam penelitian ini terdiri atas:

1. Faktor Siswa

Yaitu siswa kelas XI SMK Wonokromo

Surabaya yang bertujuan untuk meneliti tingkat kemampuan siswa dalam belajar PKn.

2. Faktor metode pembelajaran

Menyelidiki apakah penerapan metode dialog dapat digunakan secara efektif untuk meningkatkan kemampuan belajar PKn siswa dan kendala-kendala yang dihadapi selama proses pembelajaran dengan metode dialog pada siswa.

3. Faktor Guru

Menyelidiki langkah-langkah yang ditempuh oleh seorang guru dalam menyelesaikan problem yang dihadapi siswa di kelas dan langkah pemecahannya.

Sampel adalah sebagian atau wakil populasi yang diteliti (Arikunto, 2006:131). Sampel dalam penelitian ini adalah Pemilihan orang sebagai subyek penelitian tidak ditetapkan secara kaku tetapi fleksibel, hanya beberapa syarat yang harus dipenuhi yaitu jujur dapat dipercaya, taat pada janji, memiliki pengetahuan dan pengalaman tentang latar belakang penelitian.

\section{Lokasi Penelitian}

Lokasi penelitian ini ada di kelas XI di SMK Wonokromo Surabaya yang dilaksanakan pada semester ganjil tahun pelajaran 2013/2014.

\section{Variabel Penelitian}

Variabel yang digunakan dalam penelitian ini adalah penerapan metode dialog pada mata pelajaran PKn siswa kelas XI di SMK Wonokromo Surabaya.

\section{Metode Pengumpulan Data}

Jenis data yang dikumpulkan dalam penelitian ini terdiri dari data utama dan data tambahan. Data utama bersumber dari orang pertama atau informasi yang mengetahui secara rinci tentang permasalahan yang diteliti, sedangkan data tambahan bersumber dari dokumen-dokumen yang berhubungan dengan penelitian ini. Metode pengumpulan data yang digunakan dalam penelitian ini antara lain: observasi partisipan, wawancara mendalam, dan dokumentasi.

\section{Metode Analisis Data}

Teknik analisis data yang digunakan dalam penelitian ini adalah analisis deskriptif yakni analisa dengan penggambaran suatu penelitian baik dalam bentuk angka, tabel, dan lain sebaginya untuk menjelaskan tujuan penelitian.

\section{Analisis Deskriptif}

Indriantoro (1999:170) menyatakan bahwa Analisis Deskriptif atau Statistik Deskriptif dalam penelitian pada dasarnya merupakan proses transformasi data penelitian dalam bentuk tabulasi sehingga mudah dipahami dan diinterpretasikan. Tabulasi menyajikan 
ringkasan, pengaturan, ataupun penyusunan data dalam bentuk tabel numerik dan grafik.

\section{Uji Paired-Sample T Test}

Untuk mengetahui ada tidaknya perbedaan sebelum dan sesudah penerapan metode dialog pada mata pelajaran PKn siswa kelas XI siswa di SMK Wonokromo Surabaya maka dilakukan dengan Paired-Sample T Test atau lebih dikenal dengan pre-post design, yakni analisis dengan melibatkan dua pengukuran pada subyek yang sama terhadap suatu pengaruh atau perlakuan tertentu. Pengukuran pertama dilakukan sebelum diberi perlakuan tertentu dan pengukuran kedua dilakukan sesudahnya. Dasar pemikirannya sederhana, yaitu bahwa apabila suatu perlakuan tidak memberi pengaruh maka perbedaan rata-rata adalah nol. (Trihendradi, 2005:141).

Dalam penelitian ini Paired-Sample $T$ Test dilakukan untuk mengetahui ada tidaknya perbedaan yang signifikan sebelum dan sesudah penerapan metode dialog pada mata pelajaran PKn. Sebelum melakukan pengujian dengan Paired-Sample $T$ Test maka lebih dulu dilakukan uji kenormalan data.

Menurut Santoso (2001:214) uji normalitas data adalah suatu pengujian yang digunakan untuk mengetahui apakah model regresi, variabel dependen, variabel independen atau keduanya mempunyai distribusi normal atau mendekati normal.

Distribusi normal merupakan distribusi teoritis dari variabel random yang kontinyu. Kurva yang menggambarkan distribusi normal adalah kurva yang berbentuk simetris. Penggunaan dari distribusi normal berhubungan erat dengan problem penarikan sampel (Dajan, 1986: 189-190). Untuk menguji apakah sampel penelitian merupakan jenis distribusi normal maka digunakan pengujian Kolmogorov-Smirnov Goodness of Fit Test (uji $\mathrm{K}-\mathrm{S}$ ), yaitu uji normalitas secara nonparametrik terhadap masing-masing variabel. Adapun langkah-langkahnya sebagai berikut:

a) Hipotesis :

1) Ho : data berdistribusi normal

2) $\mathrm{H}_{\mathrm{i}}$ : data tidak berdistribusi normal

b) Nilai K-S hitung dalarn pengujian statistik dengan uji K-S diberi imbol dan yang dapat diperoleh dengan menggunakan

formula:

Dn $=\operatorname{Max}\left|F_{e}-F_{o}\right|$

Dimana:

Dn $=$ Deviasi absolut yang tertinggi

$\mathrm{Fe}=$ Frekuensi harapan

Fo $=$ Frekuensi observasi

c) Kriteria Pengujian :

1) Angka signifikansi (Sig) $>\alpha 0,05$, maka data berdistribusi normal.

2) Angka signifikansi (Sig) $<\alpha 0,05$, maka data tidak berdistribusi normal.

\section{Pembahasan}

Berdasarkan hasil uji Paired Sample TTest didapatkan nilai Sig. Sebesar 0.000 yang lebih kecil dari 0.025 atau $-t_{\text {hitung }}<-t_{\text {tabel }}(-$ $10.147<-2.0227)$, maka tolak Ho yang berarti ada perbedaan nilai PKn sebelum dan setelah penerapan metode dialog pada mata pelajaran PKn signifikan. Dapat disimpulkan adanya perbedaan nilai PKn sebelum dan setelah penerapan metode dialog pada mata pelajaran PKn untuk siswa kelas XI di SMK Wonokromo Surabaya

Berdasrkan hasil observasi yang dilakukan diatas menunjukkan bahwa dengan penerapan pembelajaran yang baru ini dapat dikatakan berhasil meningkatkan kemampuan belajar PKn. Siswa semakin lebih berantusias untuk mengikuti pelajaran $\mathrm{PKn}$ karena menurut mereka pembelajaran dengan prinsip ini lebih dapat dicerna dengan mudah dan mereka tidak terlalu tertekan harus berpikir keras dalam memahami dan menjawab soal yang diberikan oleh guru. Hal ini dapat diterima dengan baik oleh siswa.

Beberapa kendala yang dihadapi guru dalam menerapkan metode dialog pada mata pelajaran PKn adalah Siswa kurang percaya diri dalam menyelesaikan setiap kegiatan yang dibebankan, adanya beberapa ciri siswa yang memiliki cara berpikir yang berbeda-beda yaitu ada yang mampu menyesuaikan diri, menyukai tantangan, bertanggungjawab, mandiri, dan ada pula yang cenderung kurang aktif.

Setiap penetapan metode pembelajaran sampai dengan implementasinya di kelas, akan berhasil jika seorang guru mampu menciptakan situasi yang mendukung proses pembelajaran 
sehingga siswa benar-benar belajar tentang sesuatu materi. Oleh karena itu setiap guru perlu menyadari bahwa prinsip-prinsip belajar tidak terwujud hanya dengan memilih metode pembelajaran semata. Dalam hal ini motivasi belajar siswa amat bergantung pada banyak variabel, misalnya tantangan, kemanfaatan hal yang dipelajari bagi siswa, kemudahan akses belajar di kelas dan sebagainya. Beberapa aspek yang pilihan yang ada hubungannya antara prinsip belajar dengan metode pembelajaran antara lain motivasi, pelibatan secara aktif, pendekatan pribadi, pentahapan, umpan balik dan transfer belajar.

\section{Kesimpulan}

Berdasarkan rumusan masalah dan hasil analisis dari penelitian didapatkan kesimpulan sebagai berikut:

1. Ada perbedaan nilai PKn sebelum dan setelah penerapan metode dialog pada mata pelajaran PKn signifikan, ini dapat dilihat pada uji Paired Sample T-Test didapatkan nilai Sig. Sebesar 0.000 yang lebih kecil dari 0.025 atau $-\mathrm{t}_{\text {hitung }}<-\mathrm{t}_{\text {tabel }}(-10.147>-$ 2.0227), maka tolak Ho yang berarti yang berarti ada perbedaan nilai PKn sebelum dan setelah pelaksanaan pelatihan guru program kelas akselerasi signifikan.

2. Penerapan metode dialog dalam pembelajaran $\mathrm{PKn}$ berhasil meningkatkan kemampuan belajar PKn siswa kelas XI di SMK Wonokromo Surabaya. Hal ini terbukti dari hasil penelitian yang dilakukan, antara lain:

a. Dengan metode dialog yaitu menekankan pada pembelajaran PKn secara dialog atau berdiskusi antara pembelajaran menyimak, membaca, berbicara, memahami dan menjawab soal ujian yang diberikan, menjadikan siswa lebih mudah memahami mata pelajaran $\mathrm{PKn}$, bersemangat dalam belajar, lebih berkonsentrasi pada materi, membuat daya pikir siswa lebih berkembang, siswa lebih berani mengemukakan pendapat dan membuat siswa lebih aktif mengungkapkan pikiran perasaan lewat kegiatan berdiskusi. b. Pembelajaran ini lebih efisien dan etektif jika diterapkan dengan baik, terutama pada mata pelajaran PKn yang ruang lingkup pengajarannya mempunyai tujuan agar siswa terampil dalam hal menyimak, berbicara, membaca, memahami dan mengerjakan soal.

3. Kendala-kendala yang dihadapi guru dalam menerapkan prinsip pembelajaran integratif pada siswa kelas XI di SMK Wonokromo Surabaya adalah:

a. Siswa kurang percaya diri dalam menyelesaikan setiap kegiatan yang dibebankan.

b. Hasil observasi peneliti di kelas memperlihatkan adanya beberapa ciri siswa yang memiliki cara berpikir yang berbeda-beda yaitu ada yang mampu menyesuaikan diri, menyukai tantangan, bertanggungjawab, mandiri, dan ada pula yang cenderung kurang aktif. Kondisi ini membutuhkan keaktifan guru dalam mengajar, sehingga kegiatan belajar mengajar tetap dapat berjalan dengan baik.

\section{Saran}

Dari hasil penelitian ini, saran yang diberikan semoga dapat berguna untuk kemajuan pengajaran PKn yang diperuntukkan kepada guru dan peneliti lain yang menggunakan metode dialog. Berikut saran yang dapat diberikan:

1. Diperoleh hasil dari penelitian ini bahwa dengan adanya penerapan metode dialog dapat mempengaruhi tingkat prestasi siswa dalam belajar. Sehubungan dengan hal itu direkomendasikan kepada berbagai pihak untuk meningkatkan pengelolaan fasilitas sekolah agar layanan pembelajaran lebih bermutu yang pada akhirnya akan meningkatkan kualitas mutu siswa-siswinya dan juga para pengajar atau guru.

2. Pembelajaran lebih diarahkan pada cara membaca, memahami dan berdiskusi, menggunakan komunikasi lisan dan tata bahasa dengan baik. Hal-hal baru diterangkan dengan berani mengemukakan pendapat di depan kelas, aktif berbicara, 
sering membaca, dan mengemukan ide atau gagasan yang bagus.

3. Keberhasilan penerapan pembelajaran dengan metode dialog perlu melibatkan berbagai pihak. Dalam hal ini, penulis menyarankan supaya pihak sekolah dan masyarakat memiliki kesadaran akan pentingnya beberapa hal, yaitu: metode dialog memiliki banyak variasi sehingga memungkinkan guru untuk mengembangkan model pembelajaran yang berbeda dengan kondisi yang ada; pihak sekolah dan masyarakat perlu memberikan dukungan baik materiil maupun non-materiil untuk menunjang keberhasilan proses belajar siswa

\section{DAFTAR PUSTAKA}

Ary Ginanjar A. (2001). Rahasia Sukses Membangun Kecerdasan Emosi dan Spiritual, ESQ, Jakarta: Penerbit Arga.

Bambang Darsono (tahun 1986, hal 69), UUD 1945, Pendidikan Pancasila dan Kewarganegaraan

Drs. Pasaribu dan Drs. Simanjuntak SH,. 2001. Hubungan Antara IQ, EQ, dan $Q A$ dengan Prestasi Studi Pada Siswa. Jurnal Anima Vol.17 no.1

Depdiknas (2002). Pendekatan Kontekstual ; Contextual Teaching and Learning. Jakarta: Direktorat PLP

Poerwodarminto, (1990). Kamus Besar Bahasa Indonesia. Jakarta. Penerbit Depdikbud.

S. Brojonegoro, (2006). Kurikulum Satuan Pendidikan: Sebuah Panduan Praktis. Bandung: Remaja Rosdakarya.

Winarno, (1989). Pengantar Penelitian Ilmiah Dasar Metode Teknik. Bandung: Tarsito. 